\title{
Theater auf dem flachen Land. Bürgerliche Öffentlichkeit zwischen Provinz und Metropole
}

Abstract: Das Erzherzogtum Österreich unter der Enns eignet sich in besonderer Weise, um die Entwicklung einer bürgerlichen Theaterlandschaft im Spannungsfeld zwischen Provinz und Metropole nachzuzeichnen, denn in der Mitte des Kronlands lag Wien, um 1900 eine der größten Städte der Welt. Der Beitrag untersucht die Formierung eines bürgerlich bestimmten Kulturbetriebs in einem Raum, der zeitgenössisch als „flaches Land“ bezeichnet wurde und ungefähr dem Gebiet des heutigen Bundeslands Niederösterreich entspricht. Dieser Theaterbetrieb nahm im I9. Jahrhundert langfristig wirksame Konturen an und blieb doch ein prekäres Phänomen. Das gilt auch für Theater als Ausdruck von bürgerlicher Öffentlichkeit, und zwar im doppelten Sinn eines vom Bürgertum getragenen Kulturphänomens und des Versprechens einer breiten Beteiligung, die über Standes- und Klassengrenzen hinausweist.

Theatre in the Countryside. The Middle Classes and the Public Sphere between the Provinces and the Metropolis. The Archduchy of Austria below the Enns is particularly suited to tracing the development of a provincial theatrical landscape and investigating its relation to the metropolis, since in the crownland's centre lay Vienna, one of the largest cities in the world around i9oo. The article therefore examines the formation of a bourgeois cultural sphere in those parts of Lower Austria that were then known as the "flat countryside" and which roughly correspond to today's federal state. During the ${ }^{\text {I }} 9^{\text {th }}$ century, there emerged a theatrical landscape whose principal features proved to be long-lasting and which nevertheless remained a precarious phenomenon. This also applies if we discuss theatre as an expression of the bourgeois public sphere - in both its sense as a theatre business sustained by the middle classes and as the promise to enable participation by a broad public beyond the boundaries of classes and estates.

Keywords: provincial theatre, middle classes (Bürgertum), civil society, Jürgen Habermas

doi.org/10.52035/noil.2021.19jh02.25

Veröffentlicht nach externer Begutachtung (doppelblind) / published after external peer review (double blind) 